Arab Univ. J. Agric. Sci., Ain Shams Univ., Cairo, 13(2), 501-511, 2005

\title{
MINIMIZING THE TRANSPLANT DECAY DEVELOPMENT VIA CA APPLICATION AND MODIFIED ATMOSPHERE INCREASED STRAWBERRY YIELD
}

[32]

Attia $^{1}$, A.A.M.; A.M. El-Gizawy ${ }^{2}$;.A. Abd-Elhafez ${ }^{2}$ and M.R.Omarah ${ }^{1}$.

\begin{abstract}
This study was carried out at the Strawberry Improvement Center Experimental Farm, Nobaria, Beheira Governorate and the Horticulture Research Station, Barrage, Kalubia Governorate during 2001/2002 and 2002/2003 seasons. The study aimed to investigate the effect of calcium nutrition $(0,13$ and $26 \mathrm{~kg} / \mathrm{fed}$. Ca) and modified atmosphere storage $\left(10,20,30\right.$ and $\left.40 \% \mathrm{CO}_{2}\right)$ on the post harvest decay of cold stored strawberry transplants and their subsequent fruit production. The results indicated that increasing the rate of calcium application during the transplant growth period and carbon dioxide concentration around transplants during the cold storage resulted in significant decrements in transplant decay, infection percentage, disease severity of roots and crowns. There was a positive relationship between calcium nutrition and early yield. Moreover, the highest calcium rate gave the highest total yield while no significant difference was noticed between control and 13 $\mathrm{kg} / \mathrm{fed}$ treatments. This study concluded that adding $\mathrm{Ca}^{++}$at $26 \mathrm{Kg} / \mathrm{fed}$ as fertigation of calcium nitrate $(13 \% \mathrm{Ca})$ to the growing strawberry transplants followed by modified atmosphere storage $\left(40 \% \mathrm{CO}_{2}\right)$ during the prolonged cold storage allowed maintenance of transplant quality and increased their yield while minimizing decay development.
\end{abstract}

Key words: Fragaria transplants, Calcium, Modified atmosphere, $\mathrm{CO}_{2}$, Decay, Yield.

\section{INTRODUCTION}

Due to the expansion of strawberry nursery cultivation, transplant production has become an important industry in Egypt. Increasing the production of high quality transplants per feddan is very desirable by strawberry nursery men.

According to the ministry of agriculture statistics, decay percent of the cold- stored transplants reaches $18-20 \%$ yearly caused by some botrytis, rizhopus and rhzioctonia fungus that develop during the eight months of cold storage period. Hugh et al (1977) concluded that Botrytis cinerea and Rhizopus Spp caused fruit rot of strawberry. Because of the nursery growing season is characterized by long periods of leaf wetness and mild temperature, botrytis infects petals, stamens, and

1- Vegetable Research Department, Horticulture Research Institute, Dokky, Gizza.

2- Horticulture Department, Fac. of Agric., Ain Shams Univ., Shobra El-Kheima. 
other floral parts as reported by Powelson (1960) and Bristow and William (1986). Legard et al (2000) found that there were significant differences among cultivars in their susceptability to Botrytis rot; Sweet Charlie was very susceptible as compared with Rosa Linda and Camarosa. Botrytis infects flowers initiated on the transplants near the end of the nursery period, i.e., October, November and December (short day time) before digging out the transplants from the nursery, and it can grow under $-2^{\circ} \mathrm{C}$ (Mertely et al 2000). Carbon dioxide increased firmness of fruit tissue, which reduced the decay infection (Larsen \& Watkins, 1995 and Numes \& Morais, 2002).

As for the best percent of $\mathrm{O}_{2}$ and $\mathrm{CO}_{2}$ to control mold and to increase field survival, Lockhart and Eaves (1966) showed that for transplants which had been stored in controlled atmospheres, these percentages varied from 2.5 to 10.0 $\% \mathrm{CO}_{2}$ and from $2.5 \%$ to $12.0 \% \mathrm{O}_{2}$. On the other hand, John (1970) indicated that no effect on mold development was noticed between high and low levels of $\mathrm{CO}_{2}$. Moreover, Lieten and Goffings (1997) indicated that the combination of low $\mathrm{O}_{2}(2.5 \%)$ and high $\mathrm{CO}_{2}(1.5 \%)$ atmosphere reduced plant survival, vigour and yield. The effect of postharvest plant pathogens of controlled atmospheres (CA) enriched with carbon monoxide (CO) at $9 \%$ was studied by EL-Goorani and Sommer (1979). They found that the suppression of strawberry postharvest plant pathogenic fungi was increased by $\mathrm{CO}_{2}(5-18 \%)$ added to the low $\mathrm{O}_{2}+\mathrm{CO}$ atmosphere.

Calcium application increased also plant and fruit calcium content and reduced fungal infection (Garcia et al 1996). Modified atmosphere storage sup- presses fungal growth of Botrytis and Rhizopus in fruits. Therefore, this study aimed to investigate the effect of calcium application and modified atmosphere on the decay and subsequent fruit production of cold stored strawberry transplants.

\section{MATERIAL AND METHODS}

This study was carried out at the Strawberry Improvement center Farm, Noubaria, for transplant production and Barrage Horticulture Research Station for fruit production during the two successive seasons of 2001 / 2002, and 2002 / 2003. Uniform Sweet Charlie Super Elite strawberry transplants (first generation from in vitro culture plants) were taken from the screen-house at the beginning of January and kept in cold storage at $-1{ }^{\circ} \mathrm{C}$ for chilling requirements until transplanting in the nursery. The sandy soil of the nursery was fumigated with methyl bromide $\left(60 \mathrm{~g} / \mathrm{m}^{2}\right) 15$ days before planting. Nursery planting dates were April 14 and 19 in the two tested seasons, respectively. The Super Elite transplants were dipped in $0.1 \%$ Benlate solution for 20 minutes then planted at $1.5 \times 1.5 \mathrm{~m}$ in plots of $25 \mathrm{~m}^{2}$. Calcium nitrate with three rates, i.e., control (without calcium), 100 and $200 \mathrm{~kg}$ (13\% ca) were applied during September, October and November months as fertigation. Complete randomized design with four replicates was used for calcium treatments. Recommended irrigation, fertilization, and pest control programs for the strawberry nurseries were followed. On January 20, representative random transplants were taken to determine number of leaves and roots, crown diameter, and calcium content of roots and crowns. Transplant diameter was measured by Vernier Caliber. Root and 
crown calcium contents were determined according to the method in AOAC (1975). Decay percent was calculated as number of transplants with non sprouted crown buds, dried transplant, brown and black crown transplant and those of deteriorated tissues in one hundred transplants. All these types of transplants should be discarded before transplanting while they are usually unmarketable.

Transplants of each experimental plot were dug out from the nursery then leaves were removed and transplants were packed in plastic bags and put in cartons of $54 \times 29 \times 25 \mathrm{~cm}$. The cartons were stored at $-1^{\circ} \mathrm{C}$ and $87-90 \mathrm{RH} \%$ and subjected to modified atmosphere with five $\mathrm{CO}_{2}$ concentrations, i.e., $0,10,20,30$ and $40 \%$ as the method of Sobrisky (1999). Fifteen treatments were then tested, i.e., three calcium rates and five $\mathrm{CO}_{2}$ concentrations in $3 \times 5$ factor arrangement in RCB design. Four cartons each has 1500 transplants were used for each concentration and calcium rate.

After cold storage, transplants from the above mentioned fifteen treatments were planted at Barrage Horticulture Research Station in four-row vaised bed system with $120 \mathrm{~cm}$ width and $40 \mathrm{~cm}$ height. Plant distances were $25 \mathrm{~cm}$ apart. Planting dates were September 13 and 3 in the two tested seasons, respectively Complete randomized block design with four replicates was adopted. The plot area was $30.6 \mathrm{~m}^{2}$ (three rows, each of $6 \mathrm{~m}$ length and $1.7 \mathrm{~m}$ width). All replicates received similar agricultural practices as regards cultivation, fertilization, irrigation, pest and disease control as commonly followed in the district. The soil texture was clay with $\mathrm{pH}$ of 7.1 and Ec of 1.06. Random samples of ten plants from each experimental plot were taken after
90 days from planting and fresh weight of leaves were calculated. Early yield was determined as weight of the first seven harvests from each experimental plot. All harvested fruits collected from each plot all over the season were weighed and total yield per feddan was then calculated.

The Fusarium was identified according to Booth (1971) and modified by Nelson et al (1983). Percentage of infection was calculated as number of infected roots in one hundred roots. Disease severity was estimated according to the formula of Horsfall and Barratt (1945). All percentages were transformed to absolute numbers for statistical analysis according to Fisher and Yates (1948). All obtained data were statistically analyzed according to Waller and Duncan (1969).

\section{RESULTS AND DISCUSSION}

\section{1-Effect of calcium application on some transplant characteristics}

Data in Table (1) show that no significant effects were noticed for calcium application on the number of leaves per transplant, the number of roots and crown diameter in the two tested years except for the number of roots in the second season.

As for calcium content, the application of calcium nitrate increased calcium accumulation in the transplant crown. Similar results were found by Garcia $\boldsymbol{e t}$ al. (1996). The high calcium nitrate level decreased calcium contents in the roots in the first season while no significant differences were noticed in the second season. 
Table 1. Effect of calcium application on some transplant characteristics before Cold Storage.

\begin{tabular}{|cccccc|}
\hline \multirow{2}{*}{$\begin{array}{c}\text { Calcium } \\
\mathrm{Ca}(\mathrm{kg} / \mathrm{fed})\end{array}$} & $\begin{array}{c}\text { Leaf } \\
\text { No. }\end{array}$ & Root No. & $\begin{array}{c}\text { Crown } \\
\text { diameter } \\
(\mathrm{cm} .)\end{array}$ & $\begin{array}{c}\mathrm{Ca} \% \mathrm{in} \\
\text { roots }\end{array}$ & $\begin{array}{c}\mathrm{Ca} \% \text { in } \\
\text { crowns }\end{array}$ \\
\cline { 2 - 6 } & \multicolumn{5}{c|}{$2001 / 2002$} \\
\hline Control (0) & $4.60 \mathrm{a}$ & $26.27 \mathrm{a}$ & $0.74 \mathrm{a}$ & $2.55 \mathrm{a}$ & $1.46 \mathrm{c}$ \\
13 & $4.25 \mathrm{a}$ & $27.47 \mathrm{a}$ & $0.82 \mathrm{a}$ & $2.50 \mathrm{a}$ & $2.68 \mathrm{~b}$ \\
26 & $4.39 \mathrm{a}$ & $27.66 \mathrm{a}$ & $0.70 \mathrm{a}$ & $2.00 \mathrm{~b}$ & $3.61 \mathrm{a}$ \\
\hline 39 Control (0) & $4.70 \mathrm{a}$ & $23.04 \mathrm{~b}$ & $0.70 \mathrm{a}$ & $2.49 \mathrm{a}$ & $1.63 \mathrm{c}$ \\
13 & $4.40 \mathrm{a}$ & $26.93 \mathrm{a}$ & $0.87 \mathrm{a}$ & $2.35 \mathrm{a}$ & $2.75 \mathrm{~b}$ \\
26 & $4.03 \mathrm{a}$ & $27.43 \mathrm{a}$ & $0.73 \mathrm{a}$ & $2.46 \mathrm{a}$ & $3.12 \mathrm{a}$ \\
\hline
\end{tabular}

Values followed by the same letter (s) do not significantly differ from each other according to Duncan's multiple range test at 5\% level.

\section{2- Effect of calcium applications on postharvest pathogens of straw- berry transplants before cold storage}

In Table (2), data show that the number of pathogens (fungus) and their frequency percent decreased in roots and crowns by using calcium nutrition. Moreover, they decreased also as calcium rate increased. Results show also that five different pathogens were isolated from control plants while only three were isolated from plants received $13 \mathrm{~kg} / \mathrm{fed}$ of $\mathrm{Ca}$. When plants were treated with $\mathrm{Ca}$ at $26 \mathrm{~kg} / \mathrm{fed}$, only Rhizoctonia solani was found in both seasons and Botrytis cinerea was found in the second season. Similar results were found by Garcia et al (1996) and Mertely et al (2000).

\section{3- Effect of calcium application on infection percent and disease severity in roots and crowns of strawberry transplants before storage}

Data in Table (3) indicate that the infection percent and disease severity in the roots and crowns before storage decreased significantly as calcium applications increased in the two experimental seasons. These results may be due to the role of calcium in tissue hardness. Similar findings were reported by Garcia et al (1996) .

\section{4- Effect of calcium application and $\mathrm{CO}_{2} \%$ during storage on decay Percentage of transplant}

The decay percentage of transplants decreased by increasing either calcium 
Table 2. Effect of calcium application on postharvest pathogens of Strawberry transplants before cold storage.

\begin{tabular}{|clcc|}
\hline $\begin{array}{c}\text { Calcium } \\
\mathrm{kg} / \mathrm{fed} \text {.Ca }\end{array}$ & Isolated fungi & $\begin{array}{c}\text { Frequency } \% \\
2001-2002\end{array}$ & $\begin{array}{c}\text { Frequency\% } \\
2002-2003\end{array}$ \\
\hline Control ( 0 ) & $\begin{array}{l}\text { Rhizoctonia solani (Roots) } \\
\text { Rhizoctonia fragaria (Roots }\end{array}$ & 10 & 20 \\
& crowns) & 13 & 15 \\
& Botrytis cinerea (Crowns) & 18 & 8 \\
& Fusarium solani (Roots) & 4 & 5 \\
& Macrophomina phascolini (crowns) & 3 & 2 \\
& Rhizoctonia solani (Roots) & 8 & 9 \\
& Fusarium moniliforme (Roots) & 3 & 5 \\
& Pythium ultimum (Roots) & 2 & 4 \\
& Rhizoctonia solani (Roots) & 5 & 5 \\
\hline & Botrytis cinerea (crowns) & -- & \\
\hline
\end{tabular}

Table 3. Effect of calcium application and modified atmosphere on infection Percent and disease severity in roots and crowns of strawberry Transplants before storage.

\begin{tabular}{|ccccc|}
\hline \multirow{2}{*}{ Calcium } & \multicolumn{3}{c|}{ Roots Crowns } \\
& \multicolumn{5}{c|}{ 2001/2002 } \\
\cline { 2 - 5 } & Infection $\%$ & Disease severely & Infection $\%$ & Disease severely \\
\cline { 2 - 5 } & $20.00 \mathrm{a}$ & $13.66 \mathrm{a}$ & $9.66 \mathrm{a}$ & $6.40 \mathrm{a}$ \\
\hline Control (0) & $8.33 \mathrm{~b}$ & $5.33 \mathrm{~b}$ & $3.50 \mathrm{~b}$ & $2.30 \mathrm{~b}$ \\
13 & $5.33 \mathrm{c}$ & $3.93 \mathrm{c}$ & $0.23 \mathrm{c}$ & $0.00 \mathrm{c}$ \\
\hline 26 & & $2002 / 2003$ & & $6.20 \mathrm{a}$ \\
\hline \multirow{2}{*}{ Control (0) } & $18.00 \mathrm{a}$ & $12.50 \mathrm{a}$ & $10.00 \mathrm{a}$ & $2.66 \mathrm{~b}$ \\
13 & $8.00 \mathrm{~b}$ & $5.10 \mathrm{~b}$ & $4.00 \mathrm{~b}$ & $0.10 \mathrm{c}$ \\
\hline 26 & $6.00 \mathrm{c}$ & $4.20 \mathrm{~b}$ & $0.00 \mathrm{c}$ & \\
\hline
\end{tabular}

Values followed by the same letter(s) do not significantly differ from each other according To Duncan's multiple range test at $5 \%$ level. . 
rate during the transplant production or $\mathrm{CO}_{2}$ concentrations around the transplants during the cold storage in the two tested seasons (Table 4). The interaction showed that the highest decay percentage was found in transplants, which was not treated with calcium and stored at normal cold storage conditions. On the other hand, the lowest decay percentage was obtained when transplants were treated with $26 \mathrm{~kg} / \mathrm{fed}$ of calcium and stored under $40 \% \mathrm{CO}_{2}$ conditions in both years. This may be attributed to increasing calcium content in transplant crowns as found in Table (1) which might decrease the deterioration of transplants, as one of the major decay problems during cold storage and decreasing the fungal growth around transplants by high $\mathrm{CO}_{2} \%$, as reported by Lockhart \& Eaves (1966);
El-Goorani \& Sommer (1979); Larsen and Watkins (1995) and Numes \& Morais (2002) .

\section{5-Effect of calcium application and $\mathrm{CO}_{2} \%$ on the infection percent and disease severity after cold storage}

Data in Table (5) indicate that increasing calcium application for the grown transplants as well as $\mathrm{CO}_{2}$ concentrations around the transplants during cold storage resulted in significant reductions in infection percent and disease severity of roots and crowns after the cold storage period in the two tested seasons. The interaction between $\mathrm{Ca}$ applications and $\mathrm{CO}_{2} \%$ showed that the highest infection percent and disease

Table 4. Effect of calcium application during transplant growth and $\mathrm{CO}_{2} \%$ during cold storage on decay percentage of strawberry transplants.

\begin{tabular}{|ccccccc|}
\hline & \multicolumn{7}{c|}{$\mathrm{CO}_{2}(\%)$} \\
Calcium (kg/fed) & \multicolumn{7}{c|}{$2001 / 2002$} \\
\cline { 2 - 7 } & 0 & 10 & 20 & 30 & 40 & Mean \\
\cline { 2 - 7 } & $32.73 \mathrm{a}$ & $16.09 \mathrm{~d}$ & $11.50 \mathrm{f}$ & $9.90 \mathrm{~g}$ & $4.47 \mathrm{i}$ & $14.94 \mathrm{~A}$ \\
Control (0) & $25.33 \mathrm{~b}$ & $15.09 \mathrm{de}$ & $8.04 \mathrm{~h}$ & $4.03 \mathrm{i}$ & $1.92 \mathrm{j}$ & $10.88 \mathrm{~B}$ \\
13 & $23.73 \mathrm{c}$ & $14.23 \mathrm{e}$ & $10.80 \mathrm{fg}$ & $2.47 \mathrm{j}$ & $0.23 \mathrm{k}$ & $10.29 \mathrm{C}$ \\
26 & $27.26 \mathrm{~A}$ & $15.14 \mathrm{~B}$ & $10.12 \mathrm{C}$ & $5.47 \mathrm{D}$ & $2.21 \mathrm{E}$ & \\
Mean & & $2002 / 2003$ & & & \\
\hline \multirow{2}{*}{ Control (0) } & $21.97 \mathrm{a}$ & $15.07 \mathrm{~b}$ & $13.27 \mathrm{bc}$ & $11.20 \mathrm{~cd}$ & $6.98 \mathrm{fe}$ & $13.70 \mathrm{~A}$ \\
13 & $20.32 \mathrm{a}$ & $14.71 \mathrm{~b}$ & $8.70 \mathrm{de}$ & $2.78 \mathrm{gh}$ & $2.66 \mathrm{gh}$ & $9.89 \mathrm{~B}$ \\
26 & $13.00 \mathrm{bc}$ & $9.99 \mathrm{~d}$ & $5.67 \mathrm{fg}$ & $1.77 \mathrm{~h}$ & $0.11 \mathrm{~h}$ & $6.11 \mathrm{C}$ \\
Mean & $18.43 \mathrm{~A}$ & $13.25 \mathrm{~B}$ & $9.31 \mathrm{C}$ & $5.25 \mathrm{D}$ & $3.25 \mathrm{E}$ & \\
\hline
\end{tabular}

Values followed by the same capital letter(s) do not significantly differ from each other according to Duncan's multiple range test at $5 \%$ level. mall letters for interaction. 
Arab Univ. J. Agric. Sci., 13(2), 2005 
severity in roots and crowns of that were not fertilized with $\mathrm{Ca}$ and stored at normal cold storage conditions. calcium concentration (26kg fed) and cold stored at $40 \% \mathrm{CO}_{2}$.

\section{6- Early and total yield}

Either calcium fertilization for the growing transplants or $\mathrm{CO}_{2}$ during the cold storage of transplants had significant effects on early and total yield in both tested seasons (Tables $6 \&$ 7). Early and total yield increased as calcium applications or $\mathrm{CO}_{2}$ increased. As for the interaction effects, results showed that the highest early and total yields were obtained from plants produced from transplants treated with the high calcium transplants were obtained from plants On the other hand, the lowest values were recorded for those treated with high rate $(26 \mathrm{~kg} / \mathrm{fed})$ then stored at $40 \% \mathrm{CO}_{2}$ conditions. On the other side, the lowest values were found in plants grown from transplants which did not receive calcium nitrate then stored at normal cold storage conditions .The results did not agree with those of Lieten and Goffings (1997). This may be due to the different $\mathrm{CO}_{2}$ concentrations used in each study. The high yield under high calcium and $\mathrm{CO}_{2} \%$ conditions was likely related to reducing root and crown rot diseases which reflected the maximum recovery, positive impact on plant growth and increases nutritional use efficiency.

Table 6. Effect of calcium application during the growth of transplants and $\mathrm{CO}_{2} \%$ during transplant storage on early yield (ton / fed.) of strawberry Plants.

\begin{tabular}{|c|c|c|c|c|c|c|}
\hline \multirow{2}{*}{$\begin{array}{l}\text { Calcium } \\
\text { (kg/fed) }\end{array}$} & \multicolumn{5}{|c|}{$\mathrm{CO}_{2}(\%)}$. & \multirow[t]{2}{*}{ Mean } \\
\hline & 0 & 10 & 20 & 30 & 40 & \\
\hline Control (0) & $1.61 \mathrm{~g}$ & $1.92 \mathrm{ef}$ & $1.70 \mathrm{fg}$ & $2.13 \mathrm{de}$ & $2.46 \mathrm{c}$ & $1.96 \mathrm{C}$ \\
\hline 13 & $1.54 \mathrm{~g}$ & $1.76 \mathrm{fg}$ & $2.44 \mathrm{c}$ & $2.01 \mathrm{e}$ & $3.44 \mathrm{~b}$ & $2.24 \mathrm{~B}$ \\
\hline 26 & $2.04 \mathrm{e}$ & $2.36 \mathrm{~cd}$ & $2.06 \mathrm{e}$ & $3.46 \mathrm{~b}$ & $3.96 \mathrm{a}$ & $2.78 \mathrm{~A}$ \\
\hline Mean & $1.73 \mathrm{D}$ & $2.01 \mathrm{C}$ & $2.07 \mathrm{C}$ & $2.53 \mathrm{~B}$ & $3.29 \mathrm{~A}$ & \\
\hline \multicolumn{7}{|c|}{$2002 / 2003$} \\
\hline Control (0) & $2.23 \mathrm{ef}$ & $2.37 \mathrm{def}$ & $2.41 \mathrm{de}$ & $2.21 \mathrm{efg}$ & $2.70 \mathrm{bc}$ & $2.38 \mathrm{C}$ \\
\hline 13 & $1.99 \mathrm{~g}$ & $2.27 \mathrm{ef}$ & $2.37 \mathrm{def}$ & $2.97 \mathrm{a}$ & $2.65 \mathrm{bc}$ & $2.45 \mathrm{~B}$ \\
\hline 26 & $2.18 \mathrm{fg}$ & $2.39 \mathrm{def}$ & $2.54 \mathrm{~cd}$ & $3.04 \mathrm{~cd}$ & $2.83 \mathrm{ab}$ & $2.60 \mathrm{~A}$ \\
\hline Mean & $2.13 \mathrm{C}$ & $2.34 \mathrm{~B}$ & $2.44 \mathrm{~B}$ & $2.74 \mathrm{~A}$ & $2.73 \mathrm{~A}$ & \\
\hline
\end{tabular}

Values followed by the same capital letter(s) do not significantly differ from each other ccording to Duncan's multiple range test at $5 \%$ level. Small letters for interact 
Table 7. Effect of calcium application during the growth of transplants and $\mathrm{CO}_{2} \%$ during transplant storage on total yield (ton / fed.) of strawberry Plants.

\begin{tabular}{|c|c|c|c|c|c|c|}
\hline \multirow{2}{*}{$\begin{array}{l}\text { Calcium } \\
\text { (kg/fed) }\end{array}$} & \multicolumn{5}{|c|}{$\begin{array}{c}\mathrm{CO}_{2}(\% .) \\
2001 / 2002\end{array}$} & \multirow{2}{*}{ Mean } \\
\hline & 0 & 10 & 20 & 30 & 40 & \\
\hline Control ( 0 ) & $14.98 \mathrm{de}$ & $14.22 \mathrm{ef}$ & $12.78 \mathrm{fg}$ & $18.58 \mathrm{c}$ & $20.23 \mathrm{bc}$ & $16.16 \mathrm{~B}$ \\
\hline 13 & $11.90 \mathrm{~g}$ & $16.32 \mathrm{~d}$ & $14.97 \mathrm{de}$ & $15.74 \mathrm{de}$ & $20.30 \mathrm{bc}$ & $15.85 \mathrm{~B}$ \\
\hline 26 & $12.71 \mathrm{fg}$ & $16.32 \mathrm{~d}$ & $21.72 b$ & $20.88 \mathrm{~b}$ & $25.71 \mathrm{a}$ & $19.47 \mathrm{~A}$ \\
\hline \multirow[t]{2}{*}{ MEAN } & $13.20 \mathrm{D}$ & $15.62 \mathrm{C}$ & $16.49 \mathrm{C}$ & $18.40 \mathrm{~B}$ & $22.08 \mathrm{~A}$ & \\
\hline & \multicolumn{6}{|c|}{$2002 / 2003$} \\
\hline Control ( 0 ) & $16.14 \mathrm{~h}$ & $16.54 \mathrm{gh}$ & 17.40 ef & $21.91 \mathrm{~b}$ & $25.02 \mathrm{a}$ & $19.40 \mathrm{~B}$ \\
\hline 13 & $16.53 \mathrm{gh}$ & $17.18 \mathrm{fg}$ & $17.72 \mathrm{ef}$ & $18.46 \mathrm{~d}$ & $21.02 \mathrm{bc}$ & $18.18 \mathrm{C}$ \\
\hline 26 & $17.83 \mathrm{df}$ & $17.91 \mathrm{de}$ & $18.46 \mathrm{~d}$ & $20.74 \mathrm{C}$ & $24.79 \mathrm{a}$ & $19.95 \mathrm{~A}$ \\
\hline MEAN & $16.83 \mathrm{D}$ & $17.21 \mathrm{D}$ & $17.86 \mathrm{C}$ & $20.37 \mathrm{~B}$ & $23.61 \mathrm{~A}$ & \\
\hline
\end{tabular}

Values followed by the same capital letter(s) do not significantly differ from each other according to Duncan's multiple range tests at 5\% level. Small letters for interaction

\section{REFERENCES}

Association of Official Agricultural Chemist (1975). Official and Tentative Methods of Analysis. The A.O.A.C. Washington, D.C., USA.

Booth, C. (1971). The Genus Fusarium. Commonwealth. Mycol. Inst., Kew, Surrey, England.

Bristow, P.R.J. and S.B. William (1986). Infection and its relevance to grey mould development. Ann. Appl. Biol. 109:545-554.
EL-Goorani, M.A. and N.F. Sommer (1979). Suppression of post-harvest plant pathogenic fungi by carbon monoxide. Phytopathology 8: 834- 838.

Fisher, R.A. and F. Yates (1948). Statical Tables for Biological, Agricultural and Medical Research, $3^{\text {rd }}$ Ed. p.146. Oliver and Boyd, Edinburg.

Garcia, J.M.; S. Herrera and A. Morilla (1996). Effects of post-harvest dips in calcium chloride on strawberry. J. Agric. Food Chem, 44: 30-33.

Horsfall, J.G. and R.W. Barratt, (1945). An improvement in grading sys- 
tem for measuring plant disease. Phytopathology, 55: 655.

Hugh, A.; H.A. Daubeny and H.S. Pepin (1977) Evaluation of strawberry clones for fruit rot resistance. J. Amer. Soc. Hort. Sci. 102 (4): 431-435.

John, T. (1970). Cold Storage and Transport of Strawberry Transplants. Marketing Research Report No. 865, Agriculture Research Service, United States Department of Agriculture, Washington, D.C.

Larsen, M. and C.B. Watkins (1995). Firmness and aroma composition of strawberry following short-term high carbon dioxide treatments. HortScience. 30(2):303-305.

Legard, D.E.; C.L. Xiao; C. Mertely and C.K. Chandler (2000). Effect of plant spacing and cultivar on incidence of Botrytis fruit rot in annual strawberry. Plant Disease 84 (5): 531-538.

Lieten, F. and G. Goffings (1997). Effect of temperature and controlled atmosphere on cold storage of strawberry plants. Acta Hort. 439:445-448.

Lockhart, C.L. and C.A. Eaves (1966). The influence of controlled atmospheres on the storage of strawberry plants.
Canadian Journal of plant Science 46:151-154.

Mertely, J.C.; C.K. Chandler; C.L. Xiaoand and D.E. Legard (2000). Comparison of sanitation and fungicides for management of Botrytis fruit rot of strawberry. Plant Disease 84 (11):11971202.

Nelson, P.E.; T.A. Toussoun and S. Marassa (1983). Fusarium species: 346. An Illustrated Manual of Identification. Pennsylvania Univ., Press Univ. Park, USA.

Numes, M.C. and A.M. Morais (2002). Fruit maturity and storage temperature influence response of strawberries to controlled atmospheres. J. Amer. Soc. Hort. Sci. 127(5): 836-842.

Powelson, R.L. (1960). Initiation of strawberry fruit rot caused by Botrytis Cinerea. Phytopathology 50: 491494.

Sobrisky, R. (1999). Fluid flow. $4^{\text {th }} \mathrm{Ed}$. Serial No. ol3-576372-×, California State University. Printice Hall. New Jersey.

Waller, R.A and D.B. Duncan (1969). Abasic rule for the symmetric multiple comparison problem. Amer. Statis. Assoc. J. 12 : 1485-1503. 


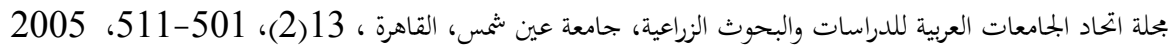

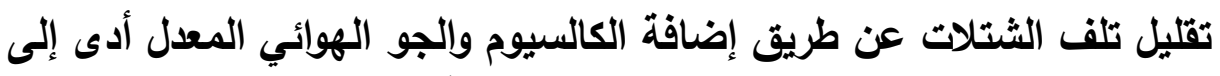
زيادة محصول الفراولة

[32]

أماني عطية عبد اللطيف- احمد محمودالجيزاوي²- احمد أبو اليزيد عبد الحافظ-ـ محمد رشاد عمارة 1

1- قسم التكاثر الخضري والبطاطس - معهل بحوث البساتين - مركز البحوث الزراعية - الجيزة- مصر

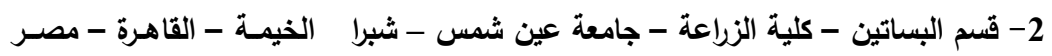

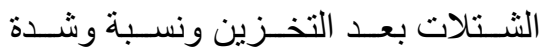

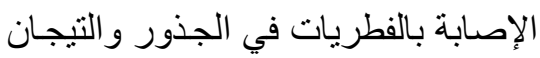

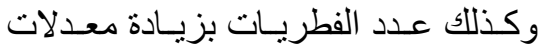
التسميد بالكالسيوم وتركيزات غلات غاز ثناني

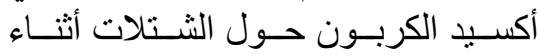

$$
\text { التخزين المبرد. }
$$

3- هناك زيادة معنويـة في المحصول المئرد المبكر

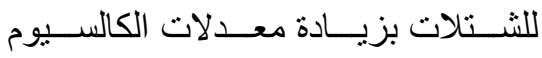

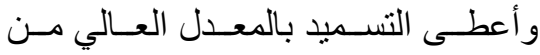

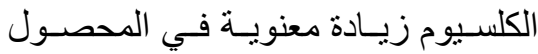

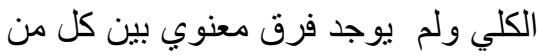

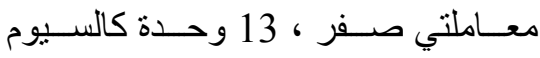
للفدان .

تجمل الدراسة انه يمكن تقليل نسبة تلف

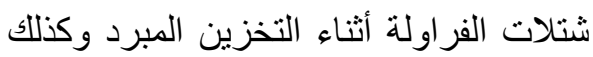

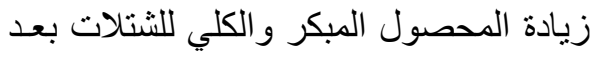
الزراعة وذلك بمعاملة الشتلات بمعدل 26

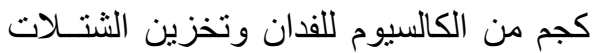
في جو هو ائي معدل ( $)$ (

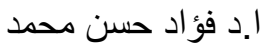

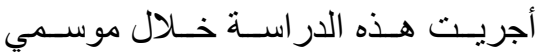

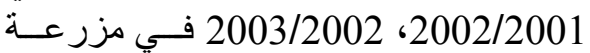

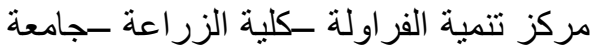

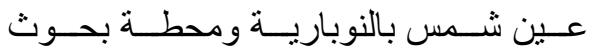
البساتين بالقناطر الخيرية بهدف دراستة واسة تأثير

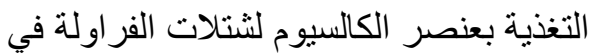

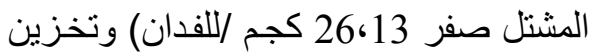
الثتلات في جو هو ائي معدل (صفر، 10، 10،

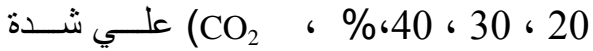
ونسبة الإصابة بالفطريات وكذللك نسبة التلف

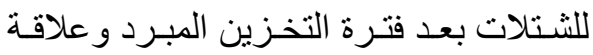
ذللك بالمحصول الكلي و المبكر للثتنات بعد بعد الترد

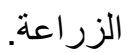

أوضحت النتائج ما يلي

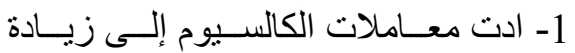
معنويه فى نسبة الكالسيوم في التيجان بينما نقص عدد الفطريـات في كل من فن لئ

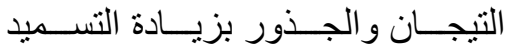

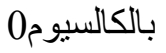
2- يوجد نقص معنوي في كل من نسبة تلف 